\title{
PERANAN PUBLIC RELATIONS \\ DALAM MEMBENTUK OPINI PUBLIK
}

Armiati

Email : armiati@fe.unp.ac.id

\begin{abstract}
This article purposed to see how public relation played rule setting public opinion both for internal and external public. Internal public includes shareholders, top executive manager, employee, and employee's family. External public includes consumer, banks, government, competitors, and community. This article concluded that public relations played important role in developing public opinion and creating harmonic relationship between firms with their public.
\end{abstract}

Kata Kunci : Public relations, Opini publik

\section{Pendahuluan}

Kegiatan public relations atau hubungan masyarakat (suatu terjemahan dalam Bahasa Indonesia) sejak dekade 70-an telah berkembang pesat sejalan dengan berkembangnya kegiatan ekonomi, bisnis/perdagangan, industri dan moneter perbankan di Indonesia, yang membutuhkan jasa-jasa informasi dan komunikasi. Bahkan kegiatan public relations di Indonesia telah memasuki bidang kegiatan lain yang lebih luas lagi, yaitu bidang politik/pemerintahan dan sosial budaya, serta pertahanan keamanan dalam era pembangunan nasional.

Untuk mendukung perkembangan public relations di Indonesia baik sebagai konsep/teori dan ilmu maupun untuk pembinaan profesional telah berkembang pula lembaga-lembaga pendidikan dan pelatihan khusus yang mendidik tenaga-tenaga dibidang komunikasi dan public relations pada tingkat akademik di berbagai perguruan tinggi atau universitas maupun pendidikan dan pelatihan yang bersifat kursus-kursus untuk mendidik tenaga terampil di bidang public relations.

Berkat pendidikan yang diselenggarakan tersebut, lahirlah public relations specialist dalam bidang international relations, pemerintahan, pendidikan, perbankan, perindustrian ringan dan berat, perdagangan dan sebagainya. Lahirnya sarjana-sarjana public relations telah memberikan harapan pada badan-badan swasta 
maupun pemerintah bahwa para pimpinan dikemudian hari akan benar-benar terlatih dan ahli dalam soal-soal teori, prinsip-prinsip dan prosedur dari fungsi baru ini.

Aktifitas public relations sehari-hari adalah menyelenggarakan komunikasi timbal balik (two way trafic communications) antara lembaga dengan pihak publik yang bertujuan untuk menciptakan saling pengertian dan dukungan bagi tercapainya suatu tujuan tertentu, kebijakan, kegiatan produksi, dan sebagainya, demi kemajuan lembaga atau citra positif lembaga bersangkutan. Jadi, kegiatan public relations tersebut sangat erat kaitannya dengan pembentukan opini publik dan perubahan sikap dari masyarakat.

Public relations berfungsi menumbuhkan hubungan baik antara segenap komponen pada suatu lembaga dalam rangka memberikan pengertian, menumbuhkan motivasi dan partisipasi. Semua ini bertujuan untuk menumbuhkan dan mengembangkan pengertian dan kemauan baik (good will) publiknya serta memperoleh opini publik yang menguntungkan atau untuk menciptakan kerjasama berdasarkan hubungan yang baik dengan publik. (Rachmadi, 1996).

Meskipun demikian, penelitian para pakar memperoleh kesimpulan bahwa masih banyak terdapat kekurangpahaman akan peranan dan vitalitas public relations itu yang tidak ditempatkan pada posisi yang seharusnya. Masih banyak pengusaha atau pimpinan perusahaan yang menganggap sepele terhadap kedudukan public relations. Apalagi ilmu public relations ini masih merupakan cabang ilmu pengetahuan baru, dan masih belum populer adanya. Para pengusaha lebih mementingkan serjana lain ketimbang sarjana public relations untuk mengisi lowongan kepala Humas atau PRO (Public Relations Officer) di perusahaannya.

Oleh karena itu perlu lebih dipopulerkan makna, guna dan manfaat public relations di tengah-tengah masyarakat, dan khususnya dalam suatu perusahaan. Nantinya diharapkan dapat tercipta suatu perusahaan yang betul-betul kuat dan mampu berkomunikasi di tengah-tengah era kompetisi dalam globalisasi sehingga diharapkan bisa turut membantu mewujudkan kesejahteraan hidup bagi semua pihak dalam pergaulannya di tengah-tengah masyarakat dunia.

Dari uraian di atas terlihat bahwa opini publik sangat mempengaruhi suatu lembaga. Penciptaan opini publik yang menguntungkan/mendukung suatu lembaga 
adalah tujuan utama public relations. Opini publik atau pendapat umum (public opinion) mempunyai kedudukan yang penting dalam kegiatan penerangan dan public relations. Oleh karena itu perlu diketahui beberapa hal tentang pengaruh dan sifat-sifat pendapat umum. Tulisan ini selanjutnya akan mencoba membahas peranan public relations dalam membentuk opini publik yang mendukung organisasi.

\section{Public relations dan Opini Publik}

The Mexican Statement yang dikutip oleh Jekkins (1996:6) dalam Kardenal (2003) menjelaskan, pertemuan asosiasi public relations seluruh dunia di Mexico City, Agustus 1978, menghasilkan pernyataan mengenai defenisi public relations sebagai berikut :

Hubungan masyarakat (public relations) adalah suatu seni sekaligus suatu disiplin ilmu sosial yang menganalisis berbagai kecenderungan, memperkirakan setiap kemungkinan konsekuensi darinya, memberi masukan dan saran-saran kepada para pemimpin organisasi serta menerapkan program-program tindakan yang terencana untuk melayani kebutuhan organisasi dan atau kepentingan khalayak.

Kegiatan public relations pada hakekatnya adalah kegiatan komunikasi, tetapi berbeda dengan jenis komunikasi lainnya. Kegiatan komunikasi dalam public relations memiliki ciri-ciri tertentu, disebabkan karena fungsi, sifat-sifat kehumasan yang berlangsung dari sifat-sifat manusia yang terlibat, terutama publik yang menjadi sasaran.

Secara umum, sasaran kegiatan public relations, baik swasta maupun pemerintah adalah menciptakan opini publik yang menguntungkan perusahaan atau lembaga pemerintah yang bersangkutan. Untuk mencapai tujuan atau sasaran tersebut, perlu diupayakan hubungan yang harmonis antara public relations dan lingkungannya.

Adapun tugas public relations sehari-hari adalah :

a. Menyelenggarakan dan bertanggungjawab atas penyampaian informasi atau pesan secara lisan, tertulis atau melalui gambar (visual) kepada publik sehingga publik mempunyai pengertian yang benar tentang hal ikhwal perusahaan atau lembaga, segenap tujuan serta kegiatan yang dilakukan. 
b. Memonitor, merekam dan mengevaluasi tanggapan serta pendapat umum atau masyarakat.

c. Mempelajari dan melakukan analisis reaksi publik terhadap kebijakan perusahaan/lembaga, maupun segala macam pendapat (public acceptance dan non-acceptance).

d. Menyelenggarakan hubungan yang baik dengan masyarakat dan media massa untuk memperoleh public favour, public opinion dan perubahan sikap.

Dari uraian tentang tugas public relations di atas, dapat kita tarik kesimpulan bahwa public relations mengemban tugas berat untuk menciptakan opini publik yang menguntungkan bagi perusahaan. Tugas tersebut tidak saja dilakukan kepada publik yang berada di luar lembaga, tetapi juga pihak publiknya melakukan kegiatan terhadap lembaga itu, sehingga terjadilah suatu pengertian bersama. Dengan pengertian demikian kita bisa mengetahui adanya sifat komunikasi dua arah dalam public relations. Dalam proses komunikasinya, public relations tidak hanya menyampaikan informasi, tetapi juga menerima informasi dari publiknya. Jadi, untuk berkomunikasi dengan tiap-tiap publik akan menimbulkan dua jalur penghubung karena itu pula public relations harus ditulis dan diartikan jamak (dengan menambahkan 's' pada kata relation).

Menurut Bird dalam bukunya The Press \& Society yang dikutip oleh Abdurrahman mengatakan bahwa opini publik adalah penilaian sosial (social Judgment) mengenai sesuatu hal yang penting dan berarti atas dasar pertukaran fikiran yang dilakukan individu-individu dengan sadar dan rasionil.

Sehubungan dengan pentingnya opini publik dan dalam public relations, perlu diketahui beberapa hal tentang pengaruhnya dan sifatnya, yaitu :

a. Opini publik dapat memperkuat Undang-undang/peraturan-peraturan, sebab tanpa dukungan opini publik, Undang-undang/peraturan-peraturan itu tidak akan jalan.

b. Opini publik merupakan pendukung moral dalam masyarakat.

c. Opini publik adalah pendukung eksistensi lembaga-lembaga sosial.

Opini dapat dinyatakan secara aktif maupun secara pasif. Opini dapat dinyatakan secara verbal, terbuka dengan kata-kata yang dapat ditafsirkan secara 
jelas ataupun melalui pilihan-pilihan kata yang sangat halus dan tidak secara langsung dapat diartikan (konotatif). Opini dapat pula dinyatakan melalui perilaku, bahasa tubuh, raut muka, simbol-simbol tertulis, pakaian yang dikenakan dan oleh tanda-tanda lain yang tak terbilang jumlahnya, melalui referensi, nilai-nilai, pandangan, sikap dan kesetiaan.

Selain itu opini dapat dinyatakan dalam bentuk lain. Opini dapat dinyatakan melalui diskusi informal, melalui surat-surat yang ditujukan kepada redaksi surat kabar secara tertutup, partisipasi pada suatu demonstrasi atau pernyataan pendapat melalui pemogokan karyawan dan sebagainya.

Memahami opini seseorang, apalagi opini publik, bukanlah sesuatu yang sederhana. Seorang praktisi public relations hendaknya dapat memahami secara berkala opini yang tengah beredar di tengah segmen publiknya. Opini tidaklah terbentuk dengan begitu saja secara sederhana. Sebelum seseorang sampai pada tindakan tertentu, orang akan membuka kembali perasaan dan rekamannya yang terbentuk di masa lalu. Maka penting sekali dipahami oleh para praktisi public relations bahwa kegiatan untuk membuat organisasi atau perusahaan disukai oleh publik bukanlah persoalan jangka pendek.

Sikap dan opini masyarakat tidaklah semata-mata dipengaruhi oleh berita tunggal yang dikeluarkan pada hari itu, melainkan oleh berita-berita yang muncul dan beredar dalam beberapa tahun belakangan secara kontinu. Semua itu akan mempengaruhi sikap masyarakat di masa depan terhadap perusahaan dan tindakantindakan yang akan dilakukan oleh masyarakat berkaitan erat dengan semua elemen yang membentuk opini mereka.

Inti tugas public relations adalah sinkronisasi antara informasi dari perusahaan dengan reaksi dan tanggapan publik sehingga mencapai suasana akrab, saling mengerti dan muncul suasana yang menyenangkan dalam interaksi perusahaan dengan publik. Persesuaian yang menciptakan hubungan harmonis dimana satu sama lain saling memberi dan menerima hal-hal yang bisa menguntungkan kedua belah pihak. Tugas public relations diarahkan melalui 2 macam tugas yaitu tugas di dalam dengan sebutan internal public relations dan tugas di luar dengan sebutan external public relations. Dengan kata lain, public relations mengemban tugas atas tujuannya 
tadi, yaitu berkomunikasi ke dalam dengan publik intern, dan ke luar dengan publik ekstern.

\section{Publik Internal}

Publik internal merupakan bagian penting yang harus diperhatikan oleh public relations dalam upaya menciptakan suasana yang harmonis di dalam badan atau perusahaan yang bersangkutan. Untuk menciptakan suasana yang menyenangkan dalam badan itu dan bagi keuntungan badan itu, komunikasi yang bersifat "two-way communication" penting sekali dan mutlak harus ada, yaitu komunikasi antara publik yang terdapat di dalam badan atau organisasi. Sebagai contoh komunikasi antara pimpinan dengan bawahan dan komunikasi antara bawahan dengan pimpinan.

Oleh karena itu adalah tugas public relations untuk menyelenggarakan komunikasi yang sifatnya persuasif dan informatif. Ia harus mengadakan analisis tentang policy kepegawaian, kebijaksanaan instansi dan kegiatan-kegiatannya, apa yang telah dilaksanakan dalam internal public relations, melakukan survey terhadap sikap karyawan dan sebagainya. Maksudnya adalah untuk mengetahui apakah sikap mereka acuh tak acuh, tidak "well-informed", ada salah pengertian dan sebagainya yang dapat menimbulkan sesuatu yang tidak diharapkan, yang memerlukan penjelasan, perbaikan-perbaikan demi tercapainya keuntungan dan kepuasan bersama.

Adalah penting untuk memahami individu-individu, latar belakang dan sikap seperti yang mereka lakukan. Penting untuk memahami keinginan-keinginannya, harapan-harapannya dan ambisi-ambisinya bahkan memahami prasangkaprasangkanya. Dengan demikian praktisi public relations harus mengetahui dan memahami tentang segala sesuatu yang ada hubungannya dengan kepentingan atau kebutuhan publik internal.

Unsur-unsur yang terdapat dalam publik internal itu adalah sebagai berikut :

a. Pemegang Saham

Kebanyakan pemilik atau pemegang saham pada perusahaan di tanah air mempunyai peranan yang sangat besar karena mayoritas saham masih dikuasai pemilik yang sama. Pada tahapan ini perusahaan tergolong sebagai perusahaan 
muda dimana perusahaan masih dinahkodai oleh pemilik, berada pada generasi pertama (dengan keterlibatan anak-anak pada generasi kedua) dan relatif dominasi pada keluarga pemilik.

Pada perusahaan muda relatif pekerjaan seorang praktisi public relations cukup rumit, hal ini disebabkan oleh :

1) Rasa percaya diri yang berlebihan pada pemilik

2) Tidak ada orang kedua di dalam perusahaan yang berani ataupun mampu mengeraksi tindakan atau opini pemilik.

3) Keasyikan pemilik pada hal-hal di luar manajemen (misalnya: pada pengembangan produk, pembinaan relasi dengan pemberian lisensi dan kewirausahaan).

4) Campur tangan anggota keluarga yang tidak mempunyai posisi formal dalam struktur organisasi.

5) Ketidakjelasan objective yang menjadi sasaran tugas seorang public relations.

6) Pemilik biasanya lebih percaya pada visi dan nalurinya dari perhitungan logis.

7) Organisasi bersifat informal dan kekeluargaan.

Dari permasalahan di atas, maka tugas public relations yang utama adalah memahami karakter pemilik beserta keluarganya, dan bersamaan dengan itu menanamkan pemahaman kepadanya tentang ruang lingkup pekerjaan public relations.

Praktisi public relations profesional akan berperan sangat penting, terutama dalam menjaga kepercayaan stakeholders lainnya terhadap perusahaan. Bila kapal hendak tenggelam, maka sebaiknya setiap awak di perusahaan memikirkan upaya untuk menyelamatkan perusahaan. Upaya praktisi public relations profesional adalah termasuk mencegah timbulnya isu-isu yang justru bisa mengakibatkan hilangnya kepercayaan stakeholders lainnya.

b. Manajer dan Top Executives

Pada perusahaan-perusahaan muda, manajer perusahaan berada di bawah kendali pemilik. Hanya dengan kapasitas yang memadailah seorang manajer 
dapat tampil secara otonom dalam mengelola perusahaan. Belakangan ini pada posisi menengah perusahaan, mulai tampak eksekutif muda yang mempunyai latar belakang pendidikan yang memadai. Para eksekutif muda ini umumnya lebih mudah memahami ruang lingkup pekerjaan-pekerjaan public relations.

Namun bagaimanapun juga, tingkat kepercayaan eksekutif muda berpendidikan terhadap public relations perusahaan amat tergantung dari wawasan intelektual praktisi public relations tersebut. Adalah kesalahan besar bila beranggapan bahwa ia bisa menjadi praktisi public relations yang baik hanya bermodalkan penampilan. Manajer-manajer profesional membutuhkan mitra yang mempunyai kapasitas manajerial dan wawasan intelektual.

Manajer dan top executive merupakan bagian dari khalayak sasaran public relations karena :

1) Manajer merupakan sumber berita majalah bisnis dan ekonomi. Pendapatnya sering diminta oleh pers berkaitan dengan peristiwa ekonomi makro, reaksi pesaing dalam industri, dan kegiatan perusahaan itu sendiri.

2) Manajer adalah sasaran pembajakan bagi perusahaan lain. Keberhasilan seorang manajer dalam bidangnya, kedekatannya dengan pers atau instansi pemerintah mengangkat nilai manajer tersebut dalam bursa "head hunter".

Public relations membantu perusahaan untuk menegakkan citranya melalui proses public relations. Sumber dari rekomendasi dan tindakan yang diambilnya adalah riset, apakah dilakukan secara formal ataupun informal. Bukan asumsi, adakalanya public relations dapat menggunakan media iklan untuk mengalihkan perhatian masyarakat atau menimbulkan kepercayaan. Public relations dapat melepas perhatian-perhatian baru, apakah melalui lobi, pendekatan terhadap pihak ketiga atau cara-cara lainnya.

c. Karyawan

Internal public relations yang baik adalah yang memperlakukan tiap karyawan dengan sikap yang sama, tanpa membeda-bedakan tingkat, pendidikan dan lain-lain. Tapi bertindak adil, tidak memihak sesuatu golongan, jujur dan bijaksana; sebab tiap anggota mulai dari pemimpin sampai dengan pesuruh merupakan bagian dari keseluruhan badan itu. 
Salah satu usaha internal public relations yang dapat menunjukkan perhatian terhadap kemajuan atau kepentingan karyawan, diantaranya mengadakan upgrading atau memberi kesempatan pada mereka untuk mengikuti pendidikan lainnya yang secara psycologis dapat menaikkan martabat mereka. Selain itu juga dengan memberikan kesempatan pada para karyawan untuk menyatukan pendapatnya dengan bebas, menyampaikan aspirasinya serta masalah-masalah yang dihadapinya untuk diperhatikan oleh pimpinan. Disinilah public relations diharapkan dapat memberikan "advice dan counsel" disamping juga bisa membawa permasalahan itu ke dalam rapat kerja.

Praktisi public relations umumnya menggunakan MBWA (Managing by Walking Around) untuk memperoleh simpati dari karyawan. Bila pimpinan puncak terlampau sibuk dengan pekerjaan strategis terhadap pihak di luar perusahaan, maka praktisi public relations harus dapat mencari manajer menengah untuk tetap melakukan komunikasi terhadap karyawan. Dan sebelum karyawan membentuk sendiri kelompoknya dengan pihak luar, praktisi public relations harus dapat menyediakan acara-acara yang sehat, seperti rekreasi, olahraga atau kesenian. Bagaimanapun juga, karyawan membutuhkan wadah paguyuban di antara mereka. Tugas public relations adalah menciptakan iklim yang baik agar karyawan dapat bekerja dengan tenang dan aman.

Rasa tidak aman pada orang-orang lapisan bawah di dalam perusahaan akan mengakibatkan mereka mencari perlindungan dari pihak-pihak di luar perusahaan. Turut campurnya pihak luar, seperti Departemen Tenaga Kerja, Kepolisian, lembaga-lembaga bantuan, dan sebagainya, menunjukkan bahwa perusahaan sudah kehilangan kepercayaan dari karyawannya.

d. Keluarga Karyawan

Akibat kurangnya informasi yang benar tentang perusahaan, keluarga karyawan sering membuat asumsi sendiri menurut pandangannya masingmasing, atau menurut informasi yang diterima dari anggota keluarga lain. Perilaku anggota keluarganya sering menjadi tidak sesuai dengan tuntutan perilaku anggota tersebut di dalam pekerjaan. Pada gilirannya gap ini akan mengganggu moral kerja karyawan. 
Dalam hal ini tugas seorang praktisi public relations adalah menimbulkan pemahaman para anggota keluarga tentang keadaan pekerjaan anggota keluarganya sehingga mereka semua dapat menyesuaikan perilakunya.

Selain menimbulkan pemahaman, seorang praktisi public relations juga perlu mendapat kepercayaan dari anggota keluarga karyawannya atas produkproduk yang dihasilkan perusahaan. Bila perusahaan dapat menghasilkan produk yang bersaing dalam kualitas, maka sebelum perusahaan memperoleh kepercayaan dari konsumen, raihlah kepercayaan dari keluarga karyawan yang turut memproduksi barang itu.

\section{Publik Eksternal}

Salah satu tujuan external public relations adalah untuk mengeratkan hubungan dengan orang-orang di luar badan/instansi hingga terbentuklah opini publik yang favourable terhadap badan itu. Bagi suatu perusahaan hubunganhubungan dengn publik di luar perusahaan itu merupakan suatu keharusan dalam usaha-usaha untuk :

a. Memperluas langganan

b. Memperkenalkan produksi

c. Mencari modal dan hubungan

d. Memperbaiki hubungan dengan serikat-serikat buruh, mencegah pemogokanpemogokan dan mempertahankan karyawan-karyawan yang cakap, efektif dan produktif dalam kerjanya.

e. Memecahkan persoalan-persoalan atau kesulitan-kesulitan yang sedang dihadapi, dan lain-lain.

Hubungan-hubungan yang harmonis dan baik dapat tercapai hanya dengan pengertian yang ikhlas, tidak dengan paksaan. Apalagi hubungan atau komunikasi itu harus berkembang dalam masyarakat demokratis. Semua komunikasi dengan publik ekstern hendaknya dilakukan perusahaan itu secara informatif dan persuasif. Informasi hendaknya diberikan secara jujur, teliti, sempurna dan berdasarkan fakta yang sebenarnya. 
Mengenai komunikasi langsung dengan publik di luar perusahaan dapat dilakukan melalui publisitas, periklanan, demonstrasi, propaganda, promosi penjualan, pameran, penerbitan panflet dan brosur, mengisi siaran radio ataupun televisi dan film, konperensi pers, penerbitan majalah, open house (menerima atau mengundang tamu) dan usaha publikasi lainnya yang mengarah pada pengenalan, penerimaan, dan simpati publik (luar) terhadap perusahaan sehingga rasa kekeluargaan dan kesediaan hidup bersama serta kerjasama antara masyarakat umumnya dan publik khususnya dengan perusahaan dapat tercapai.

Adapun unsur-unsur yang terdapat dalam publik eksternal adalah sebagai berikut :

a. Konsumen

Cabang ilmu public relations yang diarahkan pada konsumen disebut Marketing Public relations. Marketing public relations adalah proses yang terdiri atas perencanaan, implementasi dan evolusi program yang merangsang pembelian dan kepuasan konsumen melalui komunikasi yang dapat dipercaya dan menarik minat, khususnya dari perusahaan yang memenuhi kebuthan, keinginan, kehendak dan perhatian konsumen.

Memang dalam beberapa hal, pekerjaan public relations tumpang tindih dengan pekerjaan pemasaran. Namun demikian, fungsi public relations disini terutama adalah menanamkan kepercayaan kepada masyarakat dan pada konsumen akan produk yang dihasilkan oleh perusahaan.

Maka, seperti dalam pemasaran modern, public relations bekerja sebelum barang diproduksi. Dan bersama dengan praktisi pemasaran, praktisi public relations memberi masukan dan rekomendasi kepada bagian produksi atas barang yang hendak dibeli konsumen dan pelayanan yang dikehendaki. Dari situ praktisi public relations akan membuat program untuk mendukung gagasannya bahwa konsumen adalah pusat dari kegiatan bisnis perusahaan.

b. Bank

Bank yang memberi pinjaman besar kepada sebuah perusahaan umumnya akan memasang antena yang tinggi untuk mendengarkan perilaku perusahaan beserta segala kemungkinannya. Salah satu cabang ilmu public 
relations yang mendapat tugas untuk meningkatkan pemahaman bank terhadap reputasi debitur adalah Financial Relations. Lebih dari sekedar itu, Financial Relations sebenarnya dimaksudkan untuk membina kepercayaan para investor dan penyandang dana investasi agar tidak melakukan tindakan tiba-tiba untuk menarik uangnya di luar jadwal yang disepakati.

c. Pemerintah

Di Indonesia, peranan pemerintah untuk mengatur dunia usaha masih terasa cukup besar. Peran pemerintah dibutuhkan untuk menciptakan lapangan pekerjaan, menyediakan modal, melindungi para karyawan, melindungi sumber alam, mengatur hukum, mengatur dan merangsang minat investasi modal asing dan sebagainya.

Karena peranannya yang demikian besar, kebanyakan perusahaan multinasional yang beroperasi di Indonesia dan banyak perusahaan yan bergerak di sektor pertambangan secra khusus membentuk Government $P R$.

Fungsi Government $P R$ di sini adalah memantau secara berkala kebijakan pemerintah (baik yang membatasi maupun yang memberi peluang tertentu), membina hubungan baik dengan pejabat pemerintah dan melakukan lobi untuk mempercepat dan mempermuda suatu perizinan.

d. Pesaing

Suatu sistem ekonomi yang sehat selalu memperkenankan timbulnya timbulnya persaingan. Dengan adanya persaingan, timbul dorongan untuk memperbaiki kualitas produk, pelayanan, harga, dan sebagainya. Tugas public relations di sini adalah meyakinkan para manajer bahwa dalam batas-batas tertentu perusahaan dapat memanfaatkan pesaing. Alat ini disebut Marketing Control, yaitu mengukur efisiensi perusahaan dari keadaan yang ditawarkan oleh pesaing.

Dalam beberapa keadaan sering ditemui bahwa penolakan untuk memberi masuk pesaing dalam industri bukan bersumber dari pimpinan puncak perusahaan. Barrier to entry terkadang diciptakan oleh para manajer madya yang tidak menghendaki pimpinannya menggunakan market control untuk mengukur 
prestasinya. Mahalnya harga mobil di Indonesia misalnya, tidak dapat ditelusuri dari prestasi para eksekutif karena adanya proteksi.

e. Komunitas

Masyarakat yang tinggal, hidup, dan berusaha di sekitar lokasi pabrik atau perusahaan adalah salah satu unsur dari publik eksternal. Di kota-kota besar, komunitas muncul di sekitar kantor besar dalam bentuk sektor informal. Mereka mencari nafkah dengan membuka kedai makan, dan berdagang barang-barang untuk melayani karyawan perusahaan berpenghasilan menengah ke bawah. Tanpa dukungan sektor informal tersebut, perusahaan dipaksa untuk meningkatkan upah karyawannya. Pada gilirannya perusahaan tersebut akan mempunyai struktur biaya produksi yang tinggi dan kehilangan daya saing. Oleh karenanya perusahaan berkepentingan terhadap eksistensi komunitas ini.

Di daerah terpencil, komunitas merelakan tanahnya diambil perusahaan besar untuk dijadikan jalan raya, pelabuhan, lahan penggalian dan bahkan lahan pembuangan limbah. Dengan tingkat pengetahuan yang sederhana, mereka mencoba menafsirkan kehadiran perusahaan modern di sekitar komunitas mereka. Karena terjadi perubahan dari alam untuk pertanian ke alam untuk industri, besar kemungkinan mereka akan mengalami keterkejutan. Mereka ingin menawarkan tenaganya untuk bekerja di perusahaan, tetapi perusahaan lebih sering mengambil buruh dari daerah lain yang sudah mengenal "budaya kerja kantoran". Perselisihan antara perusahaan dengan komunitasnya sering berbuntut panjang. Biasanya muncul dalam bentuk pemerasan, ancaman, hingga kriminalitas, dan tidak sedikit yang mempolitisasi keadaan.

Maka, tugas public relations di sini adalah mendidik komunitas agar mereka dapat berhubungan timbal balik. Termasuk didalamnya adalah meningkatkan pengetahuan dan keterampilan mereka sebagai sumber tenaga kerja di perusahaan. Public relations juga berperan menimbulkan pemahaman akan pentingnya arti komunitas di kalangan manajer perusahaan. 


\section{Penutup}

Bidang public relations adalah suatu bidang yang sangat luas yang menyangkut hubungan dengan berbagai pihak. Pihak-pihak yang berhubungan dengan perusahaan ini dalam public relations adalah mereka yang juga disebut dengan target publik. Target publik yang pertama adalah publik internal yang terdiri dari pemegang saham, manajer dan top executives, karyawan dan keluarga karyawan. Sedangkan target publik yang kedua adalah publik eksternal yang terdiri dari konsumen, bank, pemerintah, pesaing dan komunitas. Mereka semua dapat membentuk opini di dalam masyarakat dan dapat mengangkat atau menjatuhkan citra perusahaan.

Maka dari itu public relations merupakan suatu fungsi strategi dalam menajemen yang melakukan komunikasi untuk menimbulkan pemahaman dan penerimaan dari publik. Tugas seorang praktisi public relations adalah menegakkan citra organisasi atau perusahaan yang diwakilinya agar tidak menimbulkan kesalahpahaman dan tidak melahirkan isu-isu yang dapat merugikan. Kerugian yang paling fatal tentunya adalah muncul atau timbulnya benih-benih ketidakpuasan dari pihak-pihak yang berhubungan dengan organisasi atau perusahaan. Ketidakpuasan itu dapat menimbulkan ketidakpercayaan dan dapat diwujudkan dalam bentuk penarikan diri, penarikan pinjaman dan kerja sama, tak mau jadi pelanggan lagi, sampai pada bentuk fisik, seperti pemogokan, pengrusakan dan hal-hal lain yang sifatnya merugikan.

Perhatian public relations terhadap penegakan citra berkaitan erat dengan persepsi, sikap (pendirian), dan opini orang perorangan di dalam kelompokkelompok. Semua ini adalah bahan baku bagi terbetuknya opini publik yakni opini sekelompok orang dalam segmen publik tertentu. Praktisi public relations perlu memahami semua ini, karena hanya dengan pemahaman itulah ia dapat menegakkan citra organisasi atau perusahaan dengan baik 


\section{Daftar Kepustakaan:}

Abdurrahman, Oemi. (1995). Dasar-dasar Public Relations. Bandung : PT. Citra Aditya Bakti.

Colin Coulson-Thomas. (1993). Public Relations : Pedoman Praktis Untuk Public Relations. (Terjemahan). Jakarta : Bumi Aksara.

Kardenal, Drs, M.Si. (2004). SID Mewujudkan Good Governance. Artikel : http://www.antara.co.id/seenws/?id5956. diakses pada tanggal 25 Maret 2005.

Kasali, Rhenald. (1994). Manajemen Public Relations, Konsep dan Aplikasinya di Indonesia. Jakarta : Grafiti.

Rachmadi, F. (1996). Public Relations Dalam Teori dan Praktek, Aplikasi dalam Badan Usaha Swasta dan Lembaga Pemerintah. Jakarta : PT. Gramedia Pustaka Utama.

Suhandang, Kustadi. (2004). Public Relations Perusahaan, Kajian Implementasi. Bandung: Nuansa. 